[Vicino Oriente XXIII (2019), pp. 81-93]

\title{
SOME REMARKS ON THE ACCUSATIVE IN OLD PERSIAN*
}

\author{
Maria Carmela Benvenuto - Flavia Pompeo \\ Sapienza University of Rome
}

\begin{abstract}
The most important functions of the accusative in Old Persian are consistent with those in other ancient Indo-European languages: it marks the direct object of transitive verbs, and can express the spatial notions of goal and path, as well as the temporal notion of duration. Besides these functions, there are other, in some way 'rare' or 'particular' occurrences of the Old Persian accusative that have not yet been explained, or not explained convincingly. This paper aims to investigate two interesting uses of the accusative: the double accusative construction and the mām kāma construction. The following conclusions are reached regarding the semantic roles and the functions of the accusative case in the constructions under consideration: a) a higher degree of affectedness may account for the use of the double accusative in ditransitives with some classes of verbs; $b$ ) the mām kāma construction, in turn, is a construction with a modal function, and there are some indications that in this instance the accusative could be a non-canonical subject.
\end{abstract}

Keywords: Old Persian; accusative; double accusative; ditransitives; non-canonical subject

\section{INTRODUCTION}

The ancient varieties of Indo-European (henceforth IE) languages are considered by most scholars to be "nominative-accusative" languages, that is, languages where, within the case system, the nominative encodes the function of syntactic subject of both a transitive and an intransitive verb, while the accusative expresses the direct object of a transitive verb. On the basis of syntactic and semantic parameters, these three functions are labelled in the literature on the topic as A, S and P respectively, i.e., Agent, Subject and Patient. ${ }^{1}$

Old Persian (henceforth OP) is a nominative-accusative language, as is clearly shown in examples 1 and 2, where the nominative case in preverbal position encodes $S$ (with the intransitive verb form ašiyava, from šiyav-) ${ }^{2}$ and A (with the transitive verb form avājanam) respectively, as well as controlling the verbal agreement. ${ }^{3}$ In turn, the accusative is the direct object (Gaumātam, in example 2) of the transitive verb ava-gan-. ${ }^{4}$

$$
\begin{aligned}
& \text { pasāva Kambǚjiya (S) Mudrāyam ašiyava } \\
& \text { "Afterwards Cambyses (S) went off to Egypt" (Schmitt 1991, DB 1.32-33); }{ }^{5}
\end{aligned}
$$

\footnotetext{
In the present paper, sections 1 and 3 are authored by Maria Carmela Benvenuto, while sections 2 and 4 are authored by Flavia Pompeo; section 5 is in common.

1 The term 'alignment' is generally used to refer to the different ways in which $\mathrm{A}, \mathrm{S}$ and $\mathrm{P}$ are encoded in the grammar of a given language.

2 Schmitt 2014, 248.

3 Even though OP inscriptions generally attest a rather free ordering of words, as is consistent with ancient Indo-Iranian languages, the basic word order is SOV, that is, Subject/Object/Verb (Schmitt 2004, 736).

4 Cf. Schmitt 2014, 179.

5 The OP texts and translations of the examples quoted here are taken from Schmitt's editions of Achaemenid inscriptions (Schmitt 1991; 2000; 2009).
} 
(2) avaAā adam (A) hadā kamnainbiš martiyainbiš avam Gaunāātam (P) tayam magum avājanam

"Then I (A) with a few men slew that Gaumāta the magus (P)" (Schmitt 1991, DB 1.56-57).

Since Avestan also attests this kind of alignment system, it has been reconstructed for the proto-Iranian linguistic stage.

\section{AN OVERVIEW OF THE MAIN FUNCTIONS OF THE OLD PERSIAN ACCUSATIVE}

From a brief overview of the literature on the topic, the most important functions of the accusative in OP appear to be consistent with those shown by other ancient IE languages. In particular, on the one hand the accusative has a proper "grammatical function", since it encodes the direct object of a transitive verb, as mentioned above (example 2); on the other, this case can express the more concrete notions of goal ("to") and path ("through"), thus functioning as a "local case" (Bäbirum, example 3), in addition to the temporal notion of duration ("for x time"), which is generally considered as a metaphorical extension of the spatial meaning of the case.

\section{pasāva adam kāram frāišayam Bābirum}

“Afterwards I sent forth an army to Babylon” (Schmitt 1991, DB 3.84).

Finally, it is worth mentioning that within the OP case system, the accusative is the case which occurs with the greatest number of adpositions, i.e., twelve. ${ }^{6}$

Given that, there are other, in some way "rare" or "particular", occurrences of the OP accusative that have not yet been explained, or, in our opinion, not explained convincingly. In this paper we will take into account two of these occurrences: the ditransitive double accusative construction ( $(3)$ and the mām käma construction (§ 4).

\section{The Double AcCusative CONSTRUCTION}

\subsection{Introduction}

Old Persian boasts various double accusative constructions (henceforth DAC) that differ semantically and syntactically. They include ditransitive constructions (4), object complement constructions (5) and transitive motion verbs (see example 3 above): ${ }^{7}$

xšaçam=šim adam adinam

"I despoiled him of the kingship" (Schmitt 1991, DB 1.59);

\section{(Auramazdā) mām x̌̌̄̄yatiyam akunaǔš}

"Me he made king" (Schmitt 2000, DNa 33-34).

6 For an analysis of the accusative expressing "goal" and an explanation of the differences between occurrences with or without an adposition, cf. Pompeo - Benvenuto 2008.

Some aspects of the constructions in question are discussed in Pompeo - Benvenuto (2008). 
The literature pays little attention to differences between these types of DAC in OP, discussing neither to the verbal semantics nor the properties of the accusative arguments.

As a comprehensive discussion of DACs in OP is beyond the scope of this paper, the aim of this section is to provide a description of the main properties of ditransitive constructions with a double accusative in OP. Clearly, caution is required in any such analysis due to the scarcity of textual material.

According to typological studies, the DACs are considered here as constructions consisting of ditransitive verbs with Agent (A), Theme-like (T) and Recipient-like (R) arguments. ${ }^{8}$ Given this, a DAC where the two non-agent arguments are not R and T cannot be considered a ditransitive construction. On the other hand, ditransitive constructions do not necessarily behave uniformly cross-linguistically, and differences in encoding properties (both flagging and indexing) can be found within languages.

Indeed, OP distinguishes two types of ditransitive constructions: the genitive ditransitive construction (see example 6) and the double accusative ditransitive construction (see example 4 above).

Auramazdā=mai $(\mathbf{R})$ upastām $\mathbf{( T )}$ abara

"Auramazdā brought me aid" (Schmitt 1991, DB 1.55).

The differences between these constructions, which I have recently investigated, ${ }^{9}$ seem to be determined by a lexical split. ${ }^{10}$ In particular, prototypical transfer verbs have a genitive-accusative alignment, with the Beneficiary/Addressee surfacing as genitive/dative case, ${ }^{11}$ similar to various other IE languages. On the contrary, with verbs of asking and depriving the $\mathrm{R}$ and the $\mathrm{T}$ are encoded in the same way as the Patient $(\mathrm{P})$ argument of monotransitive verbs. ${ }^{12}$ In particular, the $\mathrm{R}$ argument of this kind of ditransitive indicates a higher degree of affectedness, and is consequently marked by the accusative case.

This latter construction has been observed in previous studies, ${ }^{13}$ but it has not been examined in great depth. In the traditional view, this argument structure is simply described as a syntactic construction made up of two accusatives: one generally relating to a human entity and the other corresponding to an inanimate entity.

Malchukov - Haspelmath - Comrie 2010, 1.

This as yet unpublished study (A constructional approach to Old Persian argument structure) was presented at the STAS2018 Conference, The shaping of transitivity and argument structure: theoretical and empirical perspectives, Pavia (Italy), October 25th-27th, 2018.

10 In the simplest case, a language has just one ditransitive construction, but it is not uncommon for languages to show splits or alternations. A split is the situation where different verbs use different constructions, while an alternation is the situation where one and the same verb can occur in different constructions with roughly the same meaning (Malchukov - Haspelmath - Comrie 2010, 18).

11 In OP a syncretic process occurred merging the genitive and dative cases, with regard to their functions, in the retained genitive case (Benvenuto - Pompeo 2015).

12 Such constructions are known in the typological literature as double object constructions or neutral alignment (Malchukov - Haspelmath - Comrie 2010, 4).

13 Meillet - Benveniste 1931, 184-185; Kent 1953, 79-80; Skjærvø 2009, 106. 
In this study we consider the syntactic, semantic, pragmatic, and information structural restrictions on DACs in order to understand the factors that condition the choice between the ditransitive constructions available.

\subsection{Ditransitive verbs with double accusative}

With a limited set of verbs, both the indirect and the direct object may surface with a morphological accusative case used without a preposition. These verbs include verbs of asking and demanding, as in the verb jadiya- "to implore, ask for" (from the root $\left.\mathrm{gad}^{-}\right)^{14}$ in example (7), or depriving, as in the verb $d \bar{l}$ - "deprive, take by force" (from the root diy $\bar{a}$ "to rob") 15 in examples (8) and (4) above. They can take two accusatives, one denoting the affected person and the other the Theme.

(7) [Upon this country may not come an (enemy) army, nor crop failure nor Falsehood]

Aîta (T) adam (A) yānam (T) jadiyāmi Auramazdām (R)

"This I pray as a favour of Auramazdā together with all the gods" (Schmitt 2000, DPd 20-22);

pasāva Gaùnāta (A) haya maguš adinā Kambūjiyam (R) utā Pārsam (T) utā Mādam (T) utā aniyā dahyāva

"Afterwards Gaumāta the magus despoiled Cambises of Persia as well as of Media and the other countries" (Schmitt 1991, DB 1.46-47).

The example (7) presents a verb of asking, jadiya- "to implore, ask for". The situation is typical of a verb indicating a request ("ask for something"): both the Addressee of the request, Auramazdā-, and the requested thing, aita yāna- "this favor, gift", are in the accusative. The verb jadiya- appears another three times in the entire corpus in formulary occurrences with Auramazdā- as Addressee, sometimes with yāna- (XSc 4) and sometimes without it ( $D N a$ 54, XPh 59).

In (8) the verb $d i$ - "to take away, rob" indicates the act of depriving with a Maleficiary accusative in a situation in which an Agent takes something away from somebody.

In our examples, the DAC tends to be selected when the $\mathrm{R}$ is a definite, but not focused, noun phrase, and when the required/stolen object is the focus. Indeed, the $\mathrm{R}$ is either represented by proper nouns or, to a large extent, by personal pronouns, that is, elements that denote well-defined, generally human, entities, which have been previously mentioned in the discourse.

The factor which probably contributes to the use of asking and depriving verbs in a DAC is the asymmetry in prominence (animacy/referentiality) between the two object

Schmitt 2014, 178. The occurrences are: DPd 21, DNa 54, XPh 59f and XSc 4.

Schmitt 2014, 170. The occurrences are: $D B 1.44, D B 1.46, D B 1.59, D B 1.66$

In this case we have a kind of hyperbaton, namely, a discontinuous phrase in which the noun is preceded by its modifier, which is clearly associated with strong focus. 
arguments. In fact, «in situations where the respective roles of the two objects are disambiguated through animacy, case marking becomes dispensable» ${ }^{17}$ because the distinguishability of the argument can be indicated in other ways. In particular, it has been pointed out that «the Double Object construction is favored in cases where indirect object outranks direct object on the prominence scales, and is disfavored otherwise». ${ }^{18}$ In other words, from a cross-linguistic point of view, the asymmetry between the $\mathrm{R}$ and $\mathrm{T}$ in prominence may have played a role in determining the preferential use of neutral alignment with ditransitives.

Apart from the examples already seen above, there are other occurrences quoted in (9) and (10), which illustrate the behavioral properties of DACs as regards relativization. ${ }^{19}$

aíta xšaçam taya (T) Gaumāta (A) haya maguš adinā Kambūjiyam (R)

"That kingship, of which Gaumāta the magus despoiled Cambises, [that kingship from ancient times had belonged to our family])" (Schmitt 1991, DB 1.44-45);

(10) [I restored to the people the farmsteads, the livestock, the menials and (together with) the houses]

$\operatorname{tay} \overline{\boldsymbol{a}} \mathbf{( T )}=\operatorname{diš} \mathbf{( R )}$ Gaumāta $(\mathrm{A})$ haya maguš adinā

"Of which Gaumāta the magus had despoiled them" (Schmitt 1991, DB 1.65-66).

Despite the fact that it is not possible to generalize when drawing on a limited corpus, these occurrences betray a tendency towards a relativization of the $\mathrm{T}$ argument.

\subsection{The meaning of the construction}

Ditransitive constructions normally express a transfer event which presupposes a Recipient-like argument, given that the construal implies «a scene in which an agent participant causes an object to pass into the possession of an animate Receiver (= Recipient)». ${ }^{20}$

On the contrary, expressions involving verbs of asking or dispossession, while behaving like ditransitives, do not imply that the Agent causes the potential $\mathrm{R}$ to actually receive the $\mathrm{T}$ argument. Indeed, these kinds of verbs imply that "one causes someone to give something", not receive it. While transfer is still implied, the direction is different.

The central meaning of this construction, where $\mathrm{R}$ is marked by the accusative, is that of a "reversed transfer". What the set of "obtaining"-verbs (both asking as well as depriving) have in common is that their semantics imply some action of obtaining something from

Malchukov - Haspelmath - Comrie 2010, 50.

Malchukov - Haspelmath - Comrie 2010, 20.

19 Of the various behavioral properties of ditransitive constructions (such as incorporation, nominalization, passivization and relativization) identified by Malchukov - Haspelmath - Comrie (2010, 25), this is the only significant property of DAC observable in OP. We have found no evidence for passivization with DACs except for the controversial occurrence of the past participle ditam in $D B$ 1.48-50. Regarding the latter, the reader is referred to Filippone (2015) for the status quaestionis.

20 Malchukov - Haspelmath - Comrie 2010, 2. 
somebody, a sort of "human Source", either by taking it or asking for it. Indeed, the DAC involves the proposition of $\mathrm{R}$ not possessing $\mathrm{T}$ after the verb event. In this respect, $\mathrm{R}$ appears to be a sort of Maleficiary that ranks higher than Recipients or Beneficiaries on a scale of affectedness. ${ }^{21}$ Consequently, functional factors like the affectedness of the Maleficiary, or rather, of the malefactive-source, can explain the predisposition of obtaining verbs in a double-object construction.

\section{THE ACCUSATIVE IN THE MĀM KĀMA CONSTRUCTION}

\subsection{A description of the construction and previous studies}

The mām kāma construction occurs 22 times in the Achaemenid inscriptions in three main variants exemplified in (11), (12) and (13).

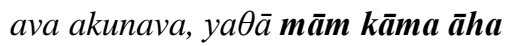

"that they did, as was my desire" (Schmitt 2000, DNa 37-38);

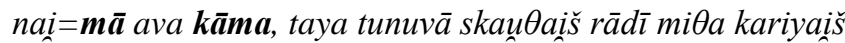

"(and) that (is) not my desire that the strong one might be treated wrongly for the weak one's sake" (Schmitt 2000, DNb 10-11);

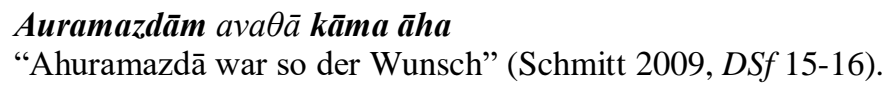

Apart from small variations, the items in the construction are generally the same, and occur in a fixed order with the obvious exception of the enclitic form - $m \bar{a}$. The first element in the construction is an accusative, denoting the entity that has the "desire/wish". In 18 occurrences of 22 this is a 1st person personal pronoun, mām (example 11) or, if enclitic, - $m \bar{a}$ (example 12), "me". This pronoun always refers to the king commissioning the inscription. In the remaining four occurrences we find the accusative of the god's name Auramazdām (example 13). ${ }^{22}$ Interestingly, the accusative is always at the beginning of the sequence and always occupies the topical position in the mām kāma construction. ${ }^{23}$

The second element of the sequence is $k \bar{a} m a$, "wish, desire", ${ }^{24}$ the nominative singular form of a relational abstract noun, attested only in this construction and in the same form, always immediately before the verb. This noun is comparable with the Avestan kāma- and

See Luraghi - Zanchi (2018, 31) and Malchukov - Haspelmath - Comrie (2010, 50).

22 The occurrences are as follows: $m \bar{a} m$ (10 times) in $D B$ 4.35-36, DB 5.17, DB 5.29, DB 5.33, DNa 37-38, DNb 11-12, DNb 26-27, DZc 12, XPl 12-13, XPl 29; -ma (8 times) in DNb 8, DNb 10, DNb 19, DNb 20, XPl 9, XPl 10-11, XPl 21, XPl 22; Auramazdām (4 times) in DSf 15-16, DSj 3, XPf 21-22, XPf 29-30.

23 There is general agreement among scholars that the choice of a word order system in OP is in part pragmatically determined. The basic word order is largely stable with the topical element largely found in the initial position, while the focal material is associated with the immediate preverbal position and the verb is generally placed at the end of the sentence; cf., among others, Hale 1988; Schmitt 2004; Skjærvø 2009.

24 Kent 1953, 179. 
Vedic kấma- ("Wunsch, Begehren, Verlangen") ${ }^{25}$ which, as noted by Kent, do not occur in constructions equivalent to the OP mām kamma. ${ }^{26}$ Even though the basic meaning that we can reconstruct for these forms is "wish, desire", it is worth noting that kāma is best translated as "will" for the OP inscriptions. This is due to the specific context marked by the authority and sacredness of the entities involved. ${ }^{27}$

Finally, in seven of the occurrences, the verb form $\bar{a} h a$ "was" (impf. of the verb $a h$ - "to be") immediately follows kāma, while in the remaining passages $\bar{a} h a$ or asti, "is", are usually implied.

Despite there being a general consensus among scholars on the meaning of the sequence, the issue becomes more complex when we consider the morpho-syntactic level. In this respect, the most significant investigation is provided in Kent's article "The accusative in Old Persian mām käma". ${ }^{28}$ Kent convincingly excludes that the accusative can be an argument of the noun käma, and explains the use of an accusative (of Goal) by assuming a diachronic replacement of an original verb of motion by a verb of state, eventually also implied, as in OP. Apart from this article, subsequent studies have only marginally touched on the construction as a whole, and on the status of the accusative in particular. In short, the accusative has been interpreted as an accusative of direction ${ }^{29}$ or of respect, ${ }^{30}$ a sub-constituent of the noun phrase which has kāma as its head, ${ }^{31}$ or, on the contrary, a clause constituent. $^{32}$

\subsection{A new interpretation}

Given this situation, a different approach based on recent linguistic research ${ }^{33}$ should be adopted in order to understand the construction better. Particularly useful studies are those on experiential expressions, which regard the broad and heterogeneous cognitive domain of experience. ${ }^{34}$ This conceptual variety is mirrored by the multiplicity of possible encodings at different levels.

It is therefore not surprising that experiential constructions constitute one of the most frequently investigated areas of research into the so-called "non-canonical" marking of arguments, which in our case, regards subjects. ${ }^{35}$ According to the description given in

5 Cf. EWA 338-339.

26 Kent 1946.

27 See also Schmitt $(2014,198)$, who translates «Wunsch, Verlangen»; for a detailed analysis, see Pompeo (2018, 245-246).

28 Kent 1946, also for other references.

Kent 1946.

Jügel 2017, 550.

Meillet - Benveniste 1931, 206-207.

Kent 1946.

Danesi (2014) has already considered the mām kāma construction from this perspective, but without examining OP occurrences.

34 For an overview of this topic and bibliographical references, cf. Verhoeven 2007.

35 In recent years the heterogeneous literature devoted to various aspects of non-canonical subjects has increased considerably; see, among others, Seržant - Kulikov (2013), to whom the reader is referred for references on the topic. 
Seržant and Kulikov, ${ }^{36}$ albeit considerably simplified, we consider that a subject conceived as a prototypical category involving properties of "subjecthood" canonically marked when the argument that scores highest regarding its pragmatic and semantic properties is encoded in a different way than what might be expected on the basis of the general alignment pattern found in a given language. In other words, the most salient argument in ancient IE languages is non-canonically marked when it is not expressed by the nominative case and does not trigger verbal agreement. Interestingly, a great variety of "subjecthood" tests have been developed, ${ }^{38}$ mostly concerning the syntactic level. ${ }^{39}$

Now let us reconsider the OP mām kāma construction. First of all, we can observe that since this construction involves a "wish/desire/will" and a human entity, it can be initially classified as an experiential expression belonging to the subdomain of volition, and in particular, to that area which involves "psycho-physical meanings", and shows an affinity and perhaps even an overlapping - with the experiential subdomain of emotion: ${ }^{40}$ the accusative encodes the Experiencer (henceforth EXP) ${ }^{41}$ and the sequence "käma (äha/asti)" constitutes the "expertum" (that is, the situation core which is generally expressed by the experiential predicate) ${ }^{42}$ The Stimulus ${ }^{43}$ is represented by a subordinate clause or, at least, by the propositional content. ${ }^{44}$

In fact, the EXP-accusative in the construction under investigation presents many characteristics of a "non-canonical subject": it refers to a [+ HUMAN] entity, and, being (largely) a $1^{\text {st }}$ person personal pronoun, is a highly individuated, definite topical element occupying the highest position in Silverstein's animacy hierarchy. ${ }^{45}$ Moreover, it is in clause-initial position and does not trigger the verbal agreement. As far as the semantics is concerned, as we will see, it is very likely that - at least at the beginning - the EXPaccusative lacked control over the event, and was actually in some way affected by it.

In order to better understand the status of the accusative in question, it is important to observe that in OP the mām kāma construction is probably involved in an ongoing process of grammaticalization resulting in a modal predicate. This can also be observed in Middle Persian. ${ }^{46}$ Indeed, this construction is always linked to a subordinate clause/propositional content, and consequently expresses the "will" for something to be done (see example 12

Seržant - Kulikov 2013.

37 There are coding properties, behavioural properties and pragmatic and semantic properties; cf. Keenan 1976.

38 Cf. Introduction in Seržant - Kulikov 2013

39 Among the criteria most frequently applied are word order, agreement, control structures, coordination patterns, anaphoric references, constraints on coreferential deletion and reflexivization (cf. Introduction in Seržant - Kulikov 2013)

40 See Verhoeven 2007, 47-49.

41 The Experiencer is «the sentient being that experiences an internal bodily or mental state, process or event» (Verhoeven 2007, 23)

42 Verhoeven 2007, 52.

43 The Stimulus is «the entity or proposition that triggers the experience or to which the experience is directed» (Verhoeven 2007, 23)

44 Cf. Pompeo 2018

45 Silverstein 1976,122

46 For an analysis of the grammaticalization path, cf. Pompeo 2018. 
above). As laid out in table 1, it is plausible that the original structure was an existential or copular sentence, where kāma constituted the syntactic subject of the verb "to be", could be modified by a dependent genitive, ${ }^{47}$ and triggered verbal agreement. Later, the construction underwent a process of reanalysis resulting in a compositional predicate " $k \bar{a} m a+(a h-)$ ", meaning "wish"/"want". During this process, the syntagmatic variability probably progressively decreased. However, given the restricted and formulaic nature of the corpus, this must remain a hypothesis. In any case, many indications - and, in particular, the fixity of the structure and the total absence of genitive as Stimuli in OP - suggest a "more verbal" - or less nominal - status of the noun kāma at that stage. ${ }^{48}$

\begin{tabular}{|c|c|c|c|c|}
\hline & $m \bar{a} m$ & $\begin{array}{c}k \bar{a} m a \\
\text { 'wish, desire' }\end{array}$ & $(a h-)$ & \\
\hline $\begin{array}{l}\text { (stage a) } \\
\text { Existential/copular } \\
\text { clause }\end{array}$ & $\begin{array}{l}\text { Accusative } \\
{[+ \text { HUMAN] }} \\
\text { entity }_{\text {ADJUNCT }}\end{array}$ & $\begin{array}{l}\text { Nominative } \\
\text { abstract } \\
\text { noun }_{\text {SUBJECT }} \\
\end{array}$ & $\begin{array}{l}\text { existential or } \\
\text { copular verb }\end{array}$ & $\begin{array}{l}\text { *genitive/subordinate clause } \\
\text { or propositional content }\end{array}$ \\
\hline $\begin{array}{l}\text { (stage b) } \\
\text { Compositional predicate, } \\
\text { with an ongoing modal } \\
\text { function }\end{array}$ & $\begin{array}{l}\text { Accusative } \\
\text { LOGICAL SUBJECT }\end{array}$ & \multicolumn{2}{|c|}{$\begin{array}{c}\text { Compositional predicate } \\
\text { (expressing modality) } \\
\text { "wish, want" }\end{array}$} & $\begin{array}{l}\text { subordinate clause } \\
\text { propositional content }\end{array}$ \\
\hline
\end{tabular}

Tab. 1 - A hypothesis of grammaticalization.

Let us briefly look at other interesting aspects. First of all, with reference to linguistic data from a comparative-historical perspective, it is important to note that constructions formally comparable to mām kāma are also attested in other ancient IE languages, although they are very rare. ${ }^{49}$ In this respect, it is worth highlighting that EXP-accusatives are comparatively less widespread than datives, just as compositional predicates are rarer than lexical verbs with an EXP-accusative, such as the Latin me pudet. ${ }^{50}$ Interestingly, as in our case, the accusative mostly occurs with intransitive predicates or when characterized by a low degree of transitivity. This is why some scholars surmise that the accusative in ProtoIndo-European was also used to encode "inactive subjects". 51

47 Genitive modifiers are attested, for example, for Vedic káma- (Kent 1946).

48 Babylonian and Elamite "translations" provide useful data to support this hypothesis, as I show in a recent paper (Il persiano antico tra conservazione e innovazione: considerazioni sulle costruzioni impersonali nelle iscrizioni achemenidi: S. Badalkhan - G.P. Basello - M. De Chiara (eds.), Iranian Studies in Honour of Adriano V. Rossi, I, Napoli, in press).

49 For examples, cf. Kent (1946) and Pompeo (2018). According to Kent (1946), this kind of construction is documented in Homeric Greek, and in some of the earliest Germanic languages. Actually, this construction is also attested in Old Church Slavonic and Old Russian, even if it is quite rare; cf. Seržant - Kulikov (2013, 328-329, and references therein). In contrast, prepositional phrases with an ExP-accusative noun are used in Celtic (Viti 2016). For a possible occurrence in Latin, cf. Lazzeroni (2002, 153).

50 To quote only some of the more recent papers, see Fedriani 2014, Viti 2016 and Dardano 2018, and respective references.

51 Cf. Lazzeroni (2002) and references therein. 
Secondly, from a synchronic perspective, in OP, where there are generally few experiential predicates, EXP-nominatives prevail over oblique Experiencers, ${ }^{2}$ and there is only one other experiential verb, varnav- "believe", always middle voice, constructed with the EXP-accusative. ${ }^{53}$

Thirdly, from a cognitive point of view, the construction with a nominative abstract noun as syntactic subject and the verb "to be" (stage a) presents quite a clear profile: indeed, the cognitive focus of the sequence is on the process, on the assertion that "something exists/is". Consequently, we can plausibly assume that the involvement of a sentient entity as an EXP is not at all essential, and, when an EXP is involved, it is seen as affected by the event, lacking control over it, and not volitional. This kind of conceptualization of the event well matches the type of sentences - quite widespread crosslinguistically - that Moreno ${ }^{54}$ calls «internal agentless impersonals». These show a tendency toward encoding through nominal sentences, and iconically reflect the lack of control over the event by the animate participant involved in it.

Given the type of event that this construction probably expresses, it seems reasonable to assume that the accusative constituted a syntactic adjunct rather than an argument. The use of the accusative in this context can, in our opinion, be explained by the interplay of semantic features - in an intransitive context the accusative encodes an "inactive participant" highly affected by the event since the accusative denotes an entity pervaded by desire - and pragmatic features, since in the construction in question the accusative expresses the human participant conceptualized as a reference point of the existential/copular expression. ${ }^{55}$

Finally, some characteristics of the Elamite "translations" allow us to exclude with some certainty that the OP structure is due to external contact. ${ }^{56}$

To conclude, the data illustrated above, and the fixity of the mām kāma construction, might well suggest the "relic" status of this construction in OP, which can be probably traced back to Proto-Indo-European.

Let us now consider the status of the accusative at stage $b$, that is, within the OP construction with an ongoing modal function. In this respect, we can observe that the development of the modal function might relate to the meaning "wish/want" that the compositional predicate "kāma + (ah-)" conveys in the OP texts. Interestingly, this meaning implies a certain degree of control and volition of the human entity over the event: in other words, the accusative with a modal verb "wish/will" could have been conceived as "more subject". Unfortunately, this hypothesis cannot be proved effectively. In fact, apart from the fact that the personal pronoun is always in clause-initial position, other syntactic

On this topic, see Viti 2016, 38-41.

53 Skjærvø $(2009,106)$ classifies the mām kāma construction and var- as «impersonal verbs», both occurring with a «personal accusative».

54 Cf. Moreno 1990.

55 On the reference point model, see, for example, Langacker 2009.

56 This issue is discussed in a recent paper (Il persiano antico tra conservazione e innovazione: considerazion sulle costruzioni impersonali nelle iscrizioni achemenidi: S. Badalkhan - G.P. Basello - M. De Chiara (eds.), Iranian Studies in Honour of Adriano V. Rossi, I, Napoli, in press). 
tests for "subjecthood" cannot be usefully applied to the Achaemenid inscriptions, given the quantitative and qualitative scarcity of the documentation, and the textual characteristics of ancient IE languages in general. ${ }^{57}$ Nevertheless, the sequence in $D N b$ 26-27 (cf. 14), which is almost identical in $X P l$ 28-31, may provide some hints regarding the "subjecthood" of $m \bar{a} m$. Indeed, the passage considered is a paratactic chain made up of four sentences. Among them, the first, the third and the fourth have an implied nominative 1st person subject adam "I", while the second sentence is an instance of the mām kāma construction. Interestingly, although this occurrence is not strictly of great use in syntactic tests of "subjecthood", the structure of the passage clearly reveals that $m \bar{a} m$ was considered "equivalent" to the other (nominative) subjects of the passage, at least at the semantic level. In other words, $m \bar{a} m$ can be considered a logical subject. ${ }^{58}$

$$
\begin{aligned}
& \text { avanā x̌̌nuta bavāmi utā mām vasaì kāma, utā uӨanduš ami } \\
& \text { utā vasai dadāmi agriyānām martiyānām. } \\
& \text { "By that I become satisfied, and it is very much my desire; and I am pleased } \\
& \text { and give generously to loyal men" (Schmitt } 2000, D N b 26-27) \text {. }
\end{aligned}
$$

\section{CONCLUSION}

On the basis of our analysis, the following generalizations can be made regarding the semantic roles and the functions of the accusative case in the constructions considered: a) a higher degree of affectedness may account for the use of the double accusative in ditransitive constructions with some classes of verbs; b) the mām kāma construction, in turn, is a construction with a modal function and there are some indications that the accusative could be a non-canonical subject.

\section{REFERENCES}

Benvenuto, M.C. - POMPEO, F.

2015 The Old Persian Genitive. A study of syncretic case: A. KRASNOwOLSKA - R. RuSEKKowALSKA (eds.), Studies on the Iranian World I: Before Islam, Krakow 2015, pp. 13-29.

DANESI, $\mathrm{S}$.

2014 Accusative subjects in Avestan: 'Errors' or non-canonically marked arguments?: IndoDARDANO, P. Iranian Journal 57.3 (2014), pp. 223-260.

2018 Zur Subjektmarkierung im Hethitischen: syntaktische und semantische Fragen: E. RIEKEN (ed.), 100 Jahre Entzifferung des Hethitischen. Morphosyntaktische Kategorien in Sprachgeschichte und Forschung, Wiesbaden 2018, pp. 39-62.

EWA $=$ MAYRHOFER, M.

1992 Etymologisches Wörterbuch des Altindoarischen, I Band, Heidelberg 1992.

57 On the feasibility of syntactic tests for ancient IE languages, see Viti 2016, fn. 1 and references therein.

58 On the overall possibility of a developmental cline from an adjunct to a non-prototypical subject, cf. Seržant Kulikov 2013, 324-331. 
FEDRIANI, C.

2014 Experiential Constructions in Latin, Leiden-Boston 2014.

FILIPPONE, E.

2015 The so-called Old Persian 'potential construction' (being Text production strategies and translation strategies in the Achaemenid documentation, III): I. SZÁNTó (ed.), From Aṣl to Zā'id: Essays in Honour of Éva M. Jeremiás, Piliscsaba 2015, pp. 27-54.

HaLe, M.

1988 Old Persian word order: Indo-Iranian Journal 31.1 (1988), pp. 27-40.

JÜGEL, TH.

2017 The Syntax of Iranian: J. KLEIN - B. JOSEPH - M. FRITZ (eds.), Handbook of Comparative KEENAN, E.L. and Historical Indo-European Linguistics, I, Berlin - Boston 2017, pp. 549-566.

1976 Towards a universal definition of 'Subject': C.N. LI (ed.), Subject and Topic, New York

KENT, R.G. 1976, pp. 303-333.

1946 The accusative in Old Persian mām kāma: Journal of the American Oriental Society 66.1 (1946), pp. 44-49.

1953 Old Persian: Grammar, Texts, Lexicon, Second edition revised, New Haven $1953^{2}$.

LANGACKER, R.W.

2009 Investigations in Cognitive Grammar, Berlin 2009.

LAZZERONI, R.

2002 Il nome greco del sogno e il neutro indoeuropeo: Archivio Glottologico Italiano 87.2 (2002), pp. 145-162.

LURAGHI, S. - ZANCHI C.

2018 Double accusative constructions and ditransitives in Ancient Greek: A. KonN - A. MalchuKov (eds.), Ditransitive Constructions in a Cross-Linguistic Perspective, Wiesbaden 2018, pp. 25-48.

MalchuKov, A. - Haspelmath, M. - COMrie, B.

2010 Ditransitive construction: a typological overview: A. MAlChuKOV - M. HASPELMATH - B Comrie (eds.), Studies in Ditransitive Constructions. A Comparative Handbook, Berlin 2010, pp. 1-64.

Meillet, A. - BenVeniste, É.

$1931 \quad$ Grammaire du vieux-perse, Paris 1931.

MORENO, J.C.

1990 Processes and actions: internal agentless impersonals in some European languages: J. BECHERT - G. BERNINI - C. BURIDANT (eds.), Toward a Typology of European Languages, POMPEO, F. Berlin - New York 1990, pp. 255-272.

2018 Tracce di grammaticalizzazione nel persiano antico: lo strano caso di mām kāma: L. Alfieri - M.C. Benvenuto - C. CianCAglini - A. De Angelis - P. Milizia - F. Pompeo (eds.), Linguistica, filologia e storia culturale. In ricordo di Palmira Cipriano, Roma 2018, pp. 237-257.

Pompeo, F. - BENVENUTO, M.C.

2008 Dal significante al contesto. Saggi sull'interpretazione di forme e strutture, Cosenza 2008

SCHMITT, R.

1991 The Bisitun Inscriptions of Darius the Great: Old Persian text (CII, Part I, I, Texts I), London 1991.

2000 The Old Persian Inscriptions of Naqsh-i Rustam and Persepolis (CII, Part I, I, Texts II), London 2000. 
2004 Old Persian: R.D. WoOdarD (ed.), The Cambridge Encyclopedia of the World's Ancient Languages, Cambridge 2004, pp. 717-741.

2009 Die altpersischen Inschriften der Achaimeniden. Editio minor mit deutscher Übersetzung, Wiesbaden 2009.

2014 Wörterbuch der altpersischen Königsinschriften, Wiesbaden 2014.

SERŽANT, I.A. - KULIKOV, L. (eds.)

2013 The Diachronic Typology of Non-Canonical Subjects, Amsterdam-Philadelphia 2013.

SILVERSTEIN, $\mathrm{M}$.

1976 Hierarchy of features and ergativity: R.M.W. DixON (ed.), Grammatical Categories in SKJÆRVø, P.O. Australian Languages, Canberra 1976, pp. 112-171.

2009 Old Iranian. Avestan and Old Persian: G. WINDFUHR (ed.), The Iranian Languages, London-New York 2009, pp. 43-195.

VERHOEVEN, E.

2007 Experiential Constructions in Yucatec Maya: A Typologically Based Analysis of a Functional Domain in a Mayan Language, Amsterdam-Philadelphia 2007.

VITI, C.

2016 Areal distribution of argument marking of Indo-European experience predicates: Journal of Indo-European Studies 44.1 (2016), pp. 1-84. 